\section{Tall Fescue Rooting as Affected by Deficit Irrigation}

\section{Jinmin Fu}

Postdoctoral Research Associate, Department of Plant Science and Landscape Architecture, University of Maryland, College Park, MD 20742

Jack Fry ${ }^{1}$

Professor, Department of Horticulture, Forestry and Recreation Resources, Kansas State University, Manhattan, KS 66506

\section{Bingru Huang \\ Professor, Department of Plant Biology and Pathology, Rutgers University, New Brunswick, NJ 08901}

\section{Additional index words. Festuca arundinacea, turfgrass, water use}

\begin{abstract}
Deficit irrigation is increasingly used to conserve water, but its impact on turfgrass rooting has not been well documented. The objective of this study was to examine the effects of deficit irrigation on 'Falcon II' tall fescue (Festuca arundinacea Schreb.) root characteristics in the field using a minirhizotron imaging system. The experiment was conducted on a silt loam soil from the first week of June to mid-Sept. 2001 and 2002 using a mobile rainout shelter under which turf received applications of $20 \%$, $60 \%$, or $100 \%$ of actual evapotranspiration (ET) twice weekly. Neither soil water content $(0$ to $25 \mathrm{~cm}$ ) nor tall fescue rooting between $4.1-$ and $50.1-\mathrm{cm}$ depths was affected by irrigation at $60 \%$ compared with $100 \%$ ET. Despite consistently lower soil water content, tall fescue irrigated at $20 \%$ ET exhibited an increase in root parameters beginning in July or August. Tall fescue subjected to $20 \%$ ET irrigation had greater total root length and surface area on two of five monitoring dates in 2002 compared with that receiving $100 \%$ ET. Evaluation of tall fescue rooting by depth indicated that root proliferation at $20 \%$ ET was occurring between $8.7-$ and $36.3-\mathrm{cm}$ depths. As evaluated under the conditions of this experiment, turfgrass managers using deficit irrigation as a water conservation strategy on tall fescue should not be concerned about a reduction in rooting deep in the soil profile, and irrigation at $20 \%$ ET may result in root growth enhancement.
\end{abstract}

Researchers have found that turfgrasses require water in amounts less than evapotranspiration (ET) to maintain acceptable visual quality (Feldhake et al., 1984; Fry and Butler, 1989; Fu et al., 2004; Qian and Engelke, 1999). Deficit irrigation is defined as supplying water in amounts less than actual ET measured under well-watered conditions and has become an increasingly popular conservation technique in turfgrass maintenance (Feldhake et al., 1984; Fry and Butler, 1989; Qian and Engelke, 1999). Irrigation deficits can be achieved by lengthening periods between irrigations or applying water more frequently at levels less than actual ET, which has been the approach of the aforementioned researchers.

Deficit irrigation in the transition zone of the United States is often practiced on tall fescue, a turfgrass that is popular in the transition zone of the United States as a result of its heat tolerance and ability to avoid

\footnotetext{
Received for publication 4 Dec. 2006. Accepted for publication 11 Feb. 2007.

We thank Turf Producers International and the Kansas Turfgrass Foundation for support of this project.

Publication no. 07-219-J of the Kansas Agricultural Experiment Station.

${ }^{1}$ To whom reprint requests should be addressed; e-mail jfry@oznet.ksu.edu
}

drought with deep rooting. However, under well-watered conditions, tall fescue has a higher ET rate when compared with most cool-season turfgrasses (Fry and Huang, 2004). In an earlier Kansas study, we found that tall fescue watered twice weekly maintained acceptable quality between June and September at deficit irrigation levels of $40 \%$ or $60 \% \mathrm{ET}$, assuming the turf manager could tolerate a period of slight decline in quality (Fu et al., 2004). When deficit irrigation is practiced in most turf situations, soil is wetted to a shallower depth than traditional deep, infrequent irrigation. Periodically wetting the surface few centimeters of soil could influence growth and distribution of roots. Roots deeper in the soil profile, however, could be exposed to drying soil, which may influence their development. Despite the positive water-saving benefits of deficit irrigation, effects of this practice on tall fescue root development have not been well evaluated.

Soil drying, but not deficit irrigation, has been evaluated for its effects on turfgrass rooting. Bennett and Doss (1960) observed that rooting of cool- and warm-season forage grasses was enhanced by allowing the surface $60 \mathrm{~cm}$ of soil to dry to $15 \%$ versus $70 \%$ of available water content. During a dry down after irrigation treatments, soil under zoysia- grass (Zoysia japonica Steud.) watered at the onset of wilt had roots extracting water at depths greater than $50 \mathrm{~cm}$, whereas soil under turf previously watered daily did not exhibit a similar drying pattern (Qian and Fry, 1996).

Measuring root changes in the field often results in error, because measurements are commonly taken by destructively sampling soil cores and determining the total roots present. The root-washing process can result in loss of a significant number of roots. The minirhizotron imaging technique allows root growth and development at a particular depth and location to be monitored in situ without destructive sampling (Huang and Liu, 2003; Upchurch and Ritchie, 1983). Murphy et al. (1994) demonstrated that determination of root length density using field cores and minirhizotron root counts was correlated $\left(\mathrm{r}^{2}=0.86\right)$ in creeping bentgrass (Agrostis palustris Huds.) and annual bluegrass (Poa annua L.). The minirhizotron technique has also been used to effectively monitor creeping bentgrass root production, growth, and mortality under field conditions (Huang and Liu, 2003; Liu and Huang, 2002).

This is the third in a series of publications investigating turfgrass responses to deficit irrigation in the transition zone, the first reporting minimum deficit irrigation levels required to maintain turf quality (Fu et al., 2004) and the second investigating deficit irrigation effects on shoot growth and physiology (Fu et al., 2006). The objective of this experiment was to monitor rooting of fieldgrown tall fescue during deficit irrigation using the minirhizotron imaging technique.

\section{Materials and Methods}

Growing conditions and treatments. This experiment was conducted at the Rocky Ford Turfgrass Research Center at Manhattan, Kan. (lat. $39.14^{\circ} \mathrm{N}$, long. $96.34^{\circ} \mathrm{W}$ ) from 4 June to 14 Sept. 2001 and from 3 June to 13 Sept. 2002. An automated, mobile rainout shelter that covered a $180-\mathrm{m}^{2}$ area was used to prevent rainfall on experimental plots. During dry weather, the shelter rested just to the north of the study area. The shelter was triggered by a minimum of $0.38 \mathrm{~mm}$ precipitation and required $\approx 2$ minutes to move south on rails and completely cover the test area. One hour after precipitation stopped, the shelter returned to its resting position. A weather station located $\approx 500 \mathrm{~m}$ from the rainout shelter monitored temperature. Mean maximum air temperatures during each month of the study (2001 and 2002, respectively) were: June, 28 and $31{ }^{\circ} \mathrm{C}$; July, 34 and $35^{\circ} \mathrm{C}$; August, 33 and $33{ }^{\circ} \mathrm{C}$; and September, 29 and $33{ }^{\circ} \mathrm{C}$. Mean minimum air temperatures for each month of the study (2001 and 2002, respectively) were: June, 16 and $18{ }^{\circ} \mathrm{C}$; July, 21 and $20^{\circ} \mathrm{C}$; August, 18 and $19^{\circ} \mathrm{C}$; and September, 14 and $17^{\circ} \mathrm{C}$.

Tall fescue was established by sodding in Spring 2000 on a river-deposited silt loam soil (fine, montmorillonitic, mesic Aquic Arguidolls), pH 6.8. Treatments consisted of irrigation levels of $20 \%, 60 \%$, and $100 \%$ 
of ET (also referred to as well-watered turf) applied to $1.18 \mathrm{~m}$ (east to west) $\times 1.83 \mathrm{~m}$ (north to south) plots. Plots were bordered by metal edging (set $15-\mathrm{cm}$ deep) to minimize lateral movement of water during application. There were no indications based on turf appearance during the study period that any subsurface lateral flow of water occurred between plots. Irrigation levels were arranged in a randomized complete block design with three replications. Two root measurement locations in each plot were subsamples.

Water was applied on Monday and Friday each week using a metered, handheld hose with a fan spray nozzle attached. Deficit irrigation amounts were determined by taking the fraction of water use of lysimetergrown turf. Lysimeters $(10.1-\mathrm{cm}$ diameter and $25-\mathrm{cm}$ deep) were constructed of polyvinyl chloride (PVC). Individual cores were sampled from the study area in Apr. 2001 using a 10.1-cm diameter cup cutter to remove a $25-\mathrm{cm}$ deep soil core and accompanying turf. Cores were then placed into PVC containers. Each lysimeter had a nylon screen on the bottom end that was secured with duct tape. After planting, lysimeters were placed in holes that had been dug in the center of each plot scheduled to receive $100 \%$ ET. The hole was only slightly larger than the lysimeter assuring no space between the turf in the lysimeter and the surrounding turf. Lysimeters were set such that the soil surface was even with the surrounding soil. Turf in lysimeters was maintained identically to that of the surrounding turf. Lysimeters remained in the field during the 2001 to 2002 winters and were used again during the 2002 study period.

The day before the study began each year, soil in lysimeters was soaked until water drained through the bottom of the container. Twenty-four hours later, two plastic bags were secured on the bottom of each lysimeter with duct tape to prevent leakage, and each lysimeter was weighed to determine its reference weight. Lysimeters were then returned to respective holes in the plot area. To determine ET, lysimeters were removed from the field and weighed with a balance providing accuracy to the nearest gram between 13:00 and 14:00 HR on Monday and Friday of each week. The mass of water lost from each lysimeter was recorded and converted to ET. Water was then added to lysimeters using a graduated cylinder to return each to its reference weight before returning to the field.
Deficit irrigation amounts for field plots were calculated as: deficit irrigation level $\times$ actual ET of well-watered turf in lysimeters $\times 267$ (a plot area adjustment factor).

Before and after study periods in each year, turf was allowed to receive natural precipitation. When drought stress was imminent, turf was watered with an in-ground irrigation system that had been installed in the study area before establishment. The plot area was watered thoroughly a few days before the beginning of the study in each year to ensure soil was at field capacity. Throughout the growing season, turf was mowed twice weekly at $5 \mathrm{~cm}$ using a walkbehind rotary mower, and clippings were collected. Nitrogen was applied at $49 \mathrm{~kg} \cdot \mathrm{ha}^{-1}$ on 3 May, 19 Sept., and 8 Nov. 2001 and 3 May, 18 Sept., and 15 Nov. 2002.

Measurements. Soil water content at a 0 to $25-\mathrm{cm}$ depth was measured weekly using a time domain reflectometer (TDR; Soil Moisture Equipment Corp., Santa Barbara, Calif.). Two steel probes, $0.63-\mathrm{cm}$ diameter by 25 $\mathrm{cm}$ long, were set vertically into the soil at a random location in each plot in Apr. 2001 and remained in place until removal at the end of the study period in Sept. 2002. Approximately $1 \mathrm{~cm}$ of each probe remained exposed at the soil surface to allow attachment to the TDR handle and periodic measurements of soil water content. A 1-cm wide block of wood, with appropriate holes drilled to accommodate probes, was used to protect the probes in the period between measurements.

Root growth and production were monitored from 4 June to 11 Sept. 2001 and from 3 June to 10 Sept. 2002 using a minirhizotron imaging technique (Upchurch and Ritchie, 1983). In May 2001, two cores (5-cm in diameter by $90-\mathrm{cm}$ long) were removed from each plot at a $45^{\circ}$ angle from the soil surface. Clear butyrate tubes were plugged with a black rubber stopper at the bottom end, sealed with waterproof silicon sealant, and manually forced into holes. On the upper side of each tube were etched frames $(1.3-\mathrm{cm}$ long by $1.8-\mathrm{cm}$ wide) that extended along the length of the tube allowing the camera to return to the exact location when repeated measurements were taken. Each tube was positioned in the ground with the upper end plugged toward the north (to minimize any light infiltration in the tube) with a black rubber stopper $\approx 1 \mathrm{~cm}$ above the soil surface such that tubes did not interfere with mowing. Within each plot, the top of one tube was positioned $40 \mathrm{~cm}$ from the east border and the top of the other $\approx 40 \mathrm{~cm}$ from the west border. Each of the tubes was $\approx 45 \mathrm{~cm}$ from the north border in each plot. Video images of roots visible against the surface of the tubes were recorded using a high-magnification minirhizotron camera (BTX-100; Bartz Technology Co., Santa Barbara, Calif.) and a camcorder (Sony Electronics, Park Ridge, N.J.). Root images were taken every 2 weeks through $43 \mathrm{~d}$ of irrigation treatments and then every 4 weeks until the end of the experiment in each year.

Video root images were recorded beginning at the fifth frame $(3.7$ to $4.6 \mathrm{~cm}$ in vertical depth) from the soil surface through to the 55th frame (49.6 to $50.6 \mathrm{~cm}$ in vertical depth). Root distribution is reported in tables as the soil depth at the midpoint of each frame.

Root images were captured as bitmap files onto a personal computer. All visible roots were traced manually in each image frame and analyzed using an image analysis program (RooTracker; Duke University, Durham, N.C.) that determines root number, length, and diameter on each image. Root surface area and volume were also calculated based on the length and diameter of roots.

Data analysis. Treatment effects were determined by analysis of variance according to the mixed procedure of Statistical Analysis System (SAS Institute, 2001). Variation was partitioned into deficit irrigation level, soil depth, and date. Differences among treatment means were separated by Fisher's least significant difference mean separation test $(P<$ $0.05)$. Initial number, length, and surface area of roots were considered as covariants to analyze covariance effects according to the general linear models of the Statistical Analysis System. The initial root images were taken on 1 June 2001 and 31 May 2002. Then, initial root numbers, lengths, and surface areas were adjusted as if each treatment had the same initial value.

\section{Results and Discussion}

Total water applied to turf receiving $100 \%$ ET during the study period in 2001 and 2002 was $562 \mathrm{~mm}$ and $598 \mathrm{~mm}$, respectively. Water applied to turf receiving $60 \%$ ET in 2001 and 2002, respectively, totaled $337 \mathrm{~mm}$ and $359 \mathrm{~mm}$. Turf irrigated at $20 \%$ ET received $112 \mathrm{~mm}$ in 2001 and $120 \mathrm{~mm}$ in 2002.

An irrigation level by date irrigation occurred in both years (Table 1). In 2001,

Table 1. Analysis of variance with mean squares and treatment significance levels

\begin{tabular}{|c|c|c|c|c|c|c|}
\hline \multirow[b]{2}{*}{ Source of variation } & \multicolumn{3}{|c|}{2001} & \multicolumn{3}{|c|}{2002} \\
\hline & No. & Length (mm) & $\begin{array}{c}\text { Surface area } \\
(\mathrm{mm})\end{array}$ & No. & Length (mm) & $\begin{array}{c}\text { Surface area } \\
(\mathrm{mm})\end{array}$ \\
\hline Irrigation level & 21.21 & 930.39 & 1713.28 & $69.24 * *$ & $3091.41 * *$ & 858.87 \\
\hline Date & $93.72 * *$ & $6566.48 * *$ & $63408.69 * *$ & $65.14 * *$ & $14137.86 * *$ & $72732.10^{* *}$ \\
\hline Soil depth & $159.83 * *$ & $9751.24 * *$ & $12640.99 * *$ & $104.99 * *$ & $10626.16^{* *}$ & $13193.40 * *$ \\
\hline Irrigation level by date & $22.91 *$ & 1339.45 & 3121.50 & $31.92 * *$ & $1407.41 * *$ & $3024.71 * *$ \\
\hline Irrigation level by soil depth & $17.93 *$ & 1385.38 & 1680.57 & $12.57 *$ & $1966.43 * *$ & $3293.93 * *$ \\
\hline Date by soil depth & 6.65 & 1111.55 & 696.16 & 7.43 & 411.57 & 1037.72 \\
\hline Irrigation level by date by soil depth & 10.52 & 1183.35 & 1117.70 & 7.03 & 365.51 & 618.47 \\
\hline
\end{tabular}

**** Significant at $P \leq 0.05$ and 0.01 , respectively. 
an increase in root number occurred at all irrigation levels from 21 June to 3 July (Table 2 ). Root number declined between 17 July and 14 Aug. at $60 \%$ and $100 \%$ ET irrigation levels, but not at $20 \% \mathrm{ET}$, which contributed to the irrigation-by-date interaction. Tall fescue receiving $20 \%$ ET had more roots on 14 Aug. and 11 Sept. compared with turf receiving $60 \%$ and $100 \% \mathrm{ET}$.

In 2002, an increase in root number, length, and surface area occurred between 13 Aug. and 10 Sept. at the 20\% ET irrigation level, but only a slight increase or decrease between the two measurement dates at $60 \%$ and $100 \%$ ET irrigation levels (Table 3 ). Tall fescue subjected to $20 \%$ ET had higher root numbers than turf irrigated at $60 \%$ ET on 10 Sept.; greater root length than turf receiving either $60 \%$ or $100 \%$ ET on 2 July, 13 Aug., and 10 Sept.; and greater surface area than turf receiving $100 \%$ ET on 2 July and 10 Sept.

Evaluation of the irrigation level by soil depth interaction (Table 1) indicated that tall fescue irrigated at $20 \%$ ET had more roots at a $17.9-\mathrm{cm}$ soil depth than that receiving $60 \%$ or $100 \%$ ET in 2001 (Table 4). Irrigation at $20 \%$ ET also resulted in higher root numbers than turf receiving $60 \%$ or $100 \%$ ET at $8.7-\mathrm{cm}, 13.3-\mathrm{cm}, 17.9-\mathrm{cm}$, and $36.3-\mathrm{cm}$ soil depths in 2002. Similarly, root surface

Table 2. Irrigation level by date interaction for root number in response to deficit irrigation on Falcon II tall fescue in 2001.

\begin{tabular}{llcl}
\hline & \multicolumn{3}{c}{ Irrigation level $(\% \text { of ET })^{\mathrm{z}}$} \\
\cline { 2 - 4 } Date & 20 & 60 & 100 \\
\hline \multirow{2}{*}{ 21 June } & $43 \mathrm{a}^{\mathrm{x}}$ & $42 \mathrm{a}$ & $59 \mathrm{a}$ \\
3 July & $57 \mathrm{a}$ & $59 \mathrm{a}$ & $71 \mathrm{a}$ \\
17 July & $51 \mathrm{a}$ & $46 \mathrm{a}$ & $44 \mathrm{a}$ \\
14 Aug. & $50 \mathrm{a}$ & $34 \mathrm{~b}$ & $34 \mathrm{~b}$ \\
11 Sept. & $51 \mathrm{a}$ & $36 \mathrm{~b}$ & $33 \mathrm{~b}$ \\
\hline
\end{tabular}

${ }^{2}$ Irrigation was applied Monday and Friday from 4 June to 14 Sept. 2001.

${ }^{y}$ Root number represents the sum of roots counted in $111.3 \times 1.8-\mathrm{cm}$ frames at depths from 4.1 to $50.1 \mathrm{~cm}$. Numbers represent the mean of three replicates.

${ }^{\mathrm{x}}$ Means in a row followed by the same letter are not significantly different based on Fisher's least significant difference mean separation test $(P \leq$ $0.05)$.

$\mathrm{ET}=$ evapotranspiration. areas were greater at the $20 \%$ ET irrigation level compared with turf receiving $60 \%$ or $100 \%$ ET at $8.7-$ and $13.3-\mathrm{cm}$ depths. Root surface area was also greater at a $17.9-\mathrm{cm}$ soil depth when tall fescue was irrigated at $20 \%$ ET compared with $100 \%$ ET but was inexplicably lower at a $22.5-\mathrm{cm}$ depth compared with turf irrigated at $100 \%$ ET, which contributed to the significant interaction observed.

One of the concerns regarding deficit irrigation, as defined here, is the potential to restrict deep rooting because the surface is periodically wetted. Soil water content at $0 \mathrm{~cm}$ to $25 \mathrm{~cm}$ was lower under tall fescue receiving $20 \%$ ET than under well-watered turf beginning after $8 \mathrm{~d}$ of irrigation in 2001 and after $7 \mathrm{~d}$ in 2002 (Fig. 1). Average irrigation amount for the $20 \%$ ET irrigation regime was $3 \mathrm{~mm}$ to $4.5 \mathrm{~mm}$, which typically wetted the soil to a depth $3 \mathrm{~cm}$ or less. Soil drying under the $20 \%$ ET regime enhanced tall fescue root development between $8.7 \mathrm{~cm}$ and $36.3 \mathrm{~cm}$. The TDR probe measures average water content over its entire $25-\mathrm{cm}$ length; as such, there were periods when the surface few centimeters were likely more wet than the rest of the profile for a short period after irrigation. This soil surface wetting could not be detected by the TDR measurement, however.

Irrigation at $60 \%$ ET had no effect on tall fescue rooting or soil water content in either year compared with turf irrigated at $100 \%$ ET. Irrigation at this level was, on average, $13 \mathrm{~mm}$ and resulted in soil wetting to a depth of $\approx 10 \mathrm{~cm}$. The lack of effect of irrigation at $60 \%$ ET irrigation compared with $100 \%$ ET irrigation on soil water level likely resulted from lower ET rates in this treatment than in turf receiving $100 \% \mathrm{ET}$. In an earlier study, irrigation at $60 \%$ ET resulted in an ET rate that was 35\% lower than in well-watered turf (Fu et al., 2002). Hence, although less water was applied to these plots, ET was also lower. Also of importance is that rooting did not proliferate at 4.7 - or $8.1-\mathrm{mm}$ depths under a $60 \%$ ET irrigation regime, depths to which the soil wetting front reached twice weekly.

Visual quality of tall fescue subjected to deficit irrigation in this experiment was discussed in detail in an earlier publication (Fu et al., 2004). Irrigation at $20 \%$ reduced visual quality below a level that was considered acceptable after $60 \mathrm{~d}$ in 2001 and $\approx 35 \mathrm{~d}$ after treatments were initiated in 2002. Irrigation at $60 \%$ ET was sufficient to maintain quality equivalent to turf receiving $100 \%$ ET throughout each summer of the experiment. Despite the reduction in visual quality at $20 \%$ ET, tall fescue rooting was concomitantly enhanced under this irrigation regime.

Moderate soil drying was reported to enhance tall fescue rooting in an earlier greenhouse study (Huang and $\mathrm{Fu}, 2001$ ). Drying the surface $0 \mathrm{~cm}$ to $20 \mathrm{~cm}$ of soil under tall fescue in the greenhouse resulted in greater root mass at $0-$ to $20-\mathrm{cm}$ and 20 - to $40-\mathrm{cm}$ depths compared with turf in which the entire $0-$ to $40-\mathrm{cm}$ soil profile was consistently maintained near field capacity. The authors also reported greater carbon allocation to roots when the surface $0 \mathrm{~cm}$ to $20 \mathrm{~cm}$ was allowed to dry, which may have resulted from a reduction in vertical shoot growth rate and photosynthesis. The same tall fescue in this study subjected to $20 \%$ ET irrigation had a vertical growth rate $\approx 40 \%$ lower, and a net photosynthesis rate $45 \%$ lower, than levels measured in well-watered turf (Fu et al., 2006). A similar reallocation of carbohydrates from shoots to roots resulting, in part, from a reduction in shoot growth may have contributed to root growth enhancement of tall fescue irrigated at $20 \%$ ET. A drier soil at the 0 - to $25-\mathrm{cm}$ depth at $20 \%$ ET irrigation in this field study also enhanced root numbers at a $36.3-\mathrm{cm}$ depth, which is congruent with the observation of Huang and Fu (2001) who reported root enhancement deep in the soil (20 to $40 \mathrm{~cm}$ ) as the surface ( 0 to $20 \mathrm{~cm})$ dried.

This is the first study to report the effects of deficit irrigation on tall fescue rooting in situ. Of greatest importance to the turfgrass manager is that there are no detrimental effects on rooting of irrigating tall fescue at $20 \%$ or $60 \%$ ET from June to September, when irrigation requirements are highest and restrictions are most common. Irrigating tall fescue at $60 \%$ ET resulted in rooting patterns the same as those observed in well-watered tall fescue. It has been suggested that shallow applications of water will encourage a proliferation of root growth near the soil surface, which did not occur at the $60 \%$ ET irrigation level. Despite a drier soil in the surface $25 \mathrm{~cm}$ under the $20 \%$ ET irrigation regime, an

Table 3. Irrigation level by date interaction for root number, length, and surface area in response to deficit irrigation on Falcon II tall fescue in 2002.

\begin{tabular}{|c|c|c|c|c|c|c|c|c|c|}
\hline \multirow[b]{2}{*}{ Date } & \multicolumn{9}{|c|}{ Irrigation level $(\% \text { of ET) })^{2}$} \\
\hline & 20 & 60 & 100 & 20 & 60 & 100 & 20 & 60 & 100 \\
\hline 16 June & $51 \mathrm{a}^{\mathrm{x}}$ & $50 \mathrm{a}$ & $64 \mathrm{a}$ & $68.2 \mathrm{a}$ & $64.6 \mathrm{a}$ & $82.4 \mathrm{a}$ & $9.7 \mathrm{a}$ & $9.6 \mathrm{a}$ & $12.6 \mathrm{a}$ \\
\hline 13 Aug. & $63 \mathrm{a}$ & $47 \mathrm{a}$ & $59 \mathrm{a}$ & $52.3 \mathrm{a}$ & $44.0 \mathrm{~b}$ & $50.3 \mathrm{ab}$ & $5.1 \mathrm{a}$ & $5.0 \mathrm{a}$ & $5.1 \mathrm{a}$ \\
\hline 10 Sept. & $82 \mathrm{a}$ & $53 \mathrm{~b}$ & $50 \mathrm{~b}$ & $60.6 \mathrm{a}$ & $47.1 \mathrm{~b}$ & $43.1 \mathrm{~b}$ & $5.8 \mathrm{a}$ & $4.9 \mathrm{ab}$ & $4.7 \mathrm{~b}$ \\
\hline
\end{tabular}

${ }^{\mathrm{Z}}$ Irrigation was applied Monday and Friday from 3 June to 13 Sept. 2002.

${ }^{\mathrm{y}}$ Root number, length, and surface area represent the sum of each in eleven $1.3 \times 1.8-\mathrm{cm}$ frames at depths from 4.1 to $50.1 \mathrm{~cm}$. Numbers represent the mean of three replicates.

${ }^{\mathrm{x}}$ Means in a row for each parameter and date followed by the same letter are not significantly different based on Fisher's least significant difference mean separation test $(P \leq 0.05)$.

$\mathrm{ET}=$ evapotranspiration 
Table 4. Irrigation level by soil depth interaction for root number, surface area, and length in response to deficit irrigation on Falcon II tall fescue in Manhattan, Kan., in 2001 and 2002.

\begin{tabular}{|c|c|c|c|c|c|c|c|c|c|c|c|c|}
\hline \multirow[b]{3}{*}{ Soil depth $(\mathrm{cm})$} & \multicolumn{3}{|c|}{2001} & \multicolumn{9}{|c|}{2002} \\
\hline & \multicolumn{12}{|c|}{ Irrigation level $(\% \text { of ET })^{z}$} \\
\hline & 20 & 60 & 100 & $20^{y}$ & 60 & 100 & 20 & 60 & 100 & 20 & 60 & $\overline{100}$ \\
\hline & \multicolumn{3}{|c|}{ Root no. ${ }^{\mathrm{y}}$} & \multicolumn{3}{|c|}{-Root no. } & \multicolumn{3}{|c|}{ Root surface area $\left(\mathrm{mm}^{2}\right)-$} & \multicolumn{3}{|c|}{ - Root length (mm) } \\
\hline 4.1 & $1.7 \mathrm{a}^{\mathrm{x}}$ & $1.9 \mathrm{a}$ & $2.2 \mathrm{a}$ & $2.1 \mathrm{a}$ & $1.9 \mathrm{a}$ & $2.1 \mathrm{a}$ & $25.9 \mathrm{a}^{\mathrm{x}}$ & $23.3 \mathrm{a}$ & $19.1 \mathrm{a}$ & $19.3 \mathrm{a}$ & $16.6 \mathrm{a}$ & $11.6 \mathrm{a}$ \\
\hline 8.7 & $5.4 \mathrm{a}$ & $4.9 \mathrm{a}$ & $4.7 \mathrm{a}$ & $5.7 \mathrm{a}$ & $3.1 \mathrm{~b}$ & $2.4 \mathrm{~b}$ & $62.3 \mathrm{a}$ & $39.3 \mathrm{~b}$ & $38.6 \mathrm{~b}$ & $52.4 \mathrm{a}$ & $31.2 \mathrm{~b}$ & $24.7 \mathrm{~b}$ \\
\hline 13.3 & $6.1 \mathrm{a}$ & $5.3 \mathrm{a}$ & $5.7 \mathrm{a}$ & $8.1 \mathrm{a}$ & $4.8 \mathrm{~b}$ & $3.9 \mathrm{~b}$ & $91.4 \mathrm{a}$ & $62.2 \mathrm{~b}$ & $58.3 \mathrm{~b}$ & $76.9 \mathrm{a}$ & $44.3 \mathrm{~b}$ & $42.0 \mathrm{~b}$ \\
\hline 17.9 & $8.8 \mathrm{a}$ & $6.6 \mathrm{~b}$ & $5.8 \mathrm{~b}$ & $10.1 \mathrm{a}$ & $5.6 \mathrm{~b}$ & $5.6 \mathrm{~b}$ & $89.8 \mathrm{a}$ & $71.6 \mathrm{ab}$ & $62.8 \mathrm{~b}$ & $80.0 \mathrm{a}$ & $62.2 \mathrm{~b}$ & $55.8 \mathrm{~b}$ \\
\hline 22.5 & $5.8 \mathrm{a}$ & $4.9 \mathrm{a}$ & $5.0 \mathrm{a}$ & $5.8 \mathrm{a}$ & $6.1 \mathrm{a}$ & $6.1 \mathrm{a}$ & $52.9 \mathrm{~b}$ & $78.6 \mathrm{ab}$ & $86.0 \mathrm{a}$ & $54.4 \mathrm{a}$ & $62.8 \mathrm{a}$ & $62.3 \mathrm{a}$ \\
\hline 27.1 & $4.9 \mathrm{a}$ & $3.8 \mathrm{a}$ & $4.5 \mathrm{a}$ & $4.6 \mathrm{a}$ & $5.1 \mathrm{a}$ & $5.9 \mathrm{a}$ & $38.2 \mathrm{a}$ & $61.6 \mathrm{a}$ & $57.7 \mathrm{a}$ & $44.5 \mathrm{a}$ & $47.0 \mathrm{a}$ & $52.8 \mathrm{a}$ \\
\hline 31.7 & $4.1 \mathrm{a}$ & $4.3 \mathrm{a}$ & $4.3 \mathrm{a}$ & $5.4 \mathrm{a}$ & $5.0 \mathrm{a}$ & $5.7 \mathrm{a}$ & $46.8 \mathrm{a}$ & $63.5 \mathrm{a}$ & $58.0 \mathrm{a}$ & $48.0 \mathrm{a}$ & $49.5 \mathrm{a}$ & $53.7 \mathrm{a}$ \\
\hline 36.3 & $3.7 \mathrm{a}$ & $3.8 \mathrm{a}$ & $4.4 \mathrm{a}$ & $7.2 \mathrm{a}$ & $4.5 \mathrm{~b}$ & $6.0 \mathrm{ab}$ & $68.2 \mathrm{a}$ & $47.0 \mathrm{a}$ & $55.5 \mathrm{a}$ & $63.1 \mathrm{a}$ & $43.4 \mathrm{a}$ & $53.4 \mathrm{a}$ \\
\hline 40.9 & $5.2 \mathrm{a}$ & $4.1 \mathrm{a}$ & $5.2 \mathrm{a}$ & $4.3 \mathrm{a}$ & $3.9 \mathrm{a}$ & $6.1 \mathrm{a}$ & $43.7 \mathrm{a}$ & $48.7 \mathrm{a}$ & $58.9 \mathrm{a}$ & $42.2 \mathrm{a}$ & $43.9 \mathrm{a}$ & $53.2 \mathrm{a}$ \\
\hline 45.5 & $3.3 \mathrm{a}$ & $3.5 \mathrm{a}$ & $2.1 \mathrm{a}$ & $4.9 \mathrm{a}$ & $4.6 \mathrm{a}$ & $5.7 \mathrm{a}$ & $49.8 \mathrm{a}$ & $52.4 \mathrm{a}$ & $69.6 \mathrm{a}$ & $46.0 \mathrm{a}$ & $52.9 \mathrm{a}$ & $58.4 \mathrm{a}$ \\
\hline 50.1 & $2.5 \mathrm{a}$ & $2.8 \mathrm{a}$ & $3.1 \mathrm{a}$ & $4.2 \mathrm{a}$ & $3.1 \mathrm{a}$ & $5.2 \mathrm{a}$ & $43.2 \mathrm{a}$ & $32.2 \mathrm{a}$ & $57.5 \mathrm{a}$ & $40.3 \mathrm{a}$ & $30.8 \mathrm{a}$ & $55.6 \mathrm{a}$ \\
\hline
\end{tabular}

zIrrigation was applied Monday and Friday from 4 June and 14 Sept. 2001 and 3 June to 13 Sept. 2002.

${ }^{y}$ Root number, surface area, and length represent means from $1.3 \times 1.8-\mathrm{cm}$ frames across three replicates and five measurement dates.

${ }^{\mathrm{x}}$ Means in a row followed by the same letter are not significantly different based on a Fisher's least significant difference mean separation test $(P \leq 0.05)$.

$\mathrm{ET}=$ evapotranspiration.

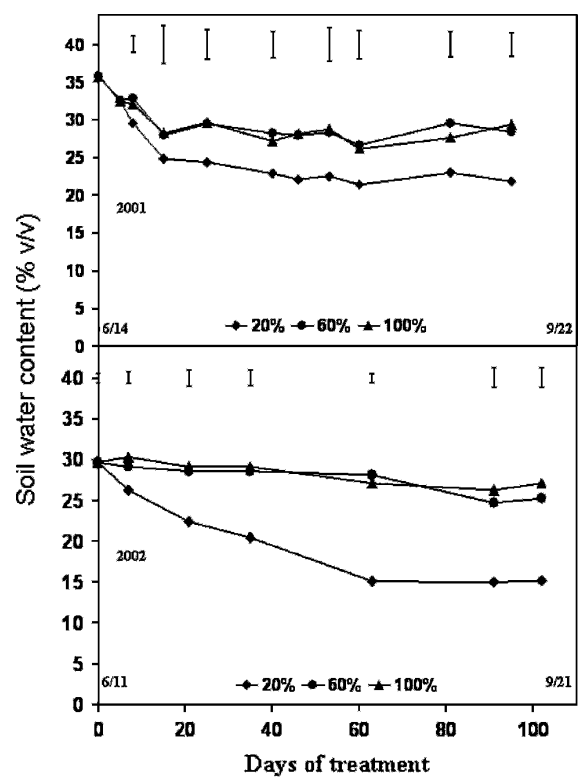

Fig. 1. Change in soil water content at a $0-$ to $25-\mathrm{cm}$ depth under 'Falcon II' tall fescue receiving $20 \%, 60 \%$, and $100 \%$ of actual evapotranspiration under a rainout shelter at Manhattan, Kan., in 2001 and 2002. Bars represented least significant difference values $(P \leq 0.05)$. increase in tall fescue root number, length, and surface area was observed to a $17.3-\mathrm{cm}$ depth, and root number enhancement occurred to a $36.3-\mathrm{cm}$ depth. As such, although quality declined under the $20 \%$ ET irrigation level, as previously reported, rooting was stimulated.

\section{Literature Cited}

Bennett, O. and B. Doss. 1960. Effect of soil moisture level on root distribution of coolseason species. Agron. J. 52:204-207.

Feldhake, C.M., R.E. Danielson, and J.D. Butler. 1984. Turfgrass evapotranspiration. II. Responses to deficit irrigation. Agron. J. 76: 85-89.

Fry, J.D. and J.D. Butler. 1989. Response of tall and hard fescue to deficit irrigation. Crop Sci. 29:1536-1541.

Fry, J. and B. Huang. 2004. Applied Turfgrass Science and Physiology. John Wiley and Sons, Hoboken, N.J.

Fu, J., J. Fry, and B. Huang. 2002. Water savings and performance of four turfgrasses under deficit irrigation. Turfgrass Research. KSU Agr. Exp. Stn. Rpt. of Prog. 892:1-5.

Fu, J., J. Fry, and B. Huang. 2004. Minimum water requirements of four turfgrasses in the transition zone. HortScience 39:1740-1744.
Fu, J., J. Fry, and B. Huang. 2007. Growth and carbon metabolism of tall fescue and zoysiagrass as affected by deficit irrigation. HortScience 42:378-381

Huang, B. and J. Fu. 2001. Growth and physiological responses of tall fescue to surface soil drying. International Turfgrass Society Research Journal. 9:291-296.

Huang, B. and X. Liu. 2003. Summer root decline: Production and mortality for four cultivars of creeping bentgrass. Crop Sci. 43:258-265.

Liu, X. and B. Huang. 2002. Mowing effects on root production, growth, and mortality of creeping bentgrass. Crop Sci. 42:1241-1250.

Murphy, J.A., M.G. Hendricks, P.E. Rieke, A.J.M. Smucher, and B.E. Branham. 1994. Turfgrass root system evaluation using the minirhizotron and video recording methods. Agron. J. $86: 247-250$.

Qian, Y.L. and M.C. Engelke. 1999. Turfgrass selection: Comparing three turfgrasses for minimum irrigation requirements, drought resistance and long-term performance. Turfgrass Trends 8:4-8.

Qian, Y. and J. Fry. 1996. Irrigation frequency affects zoysiagrass rooting and plant water status. HortScience 31:234-237.

Institute Inc, S.A.S. 2001 SAS/SAT User's Guide. Release 6.03 Ed. SAS Institute Inc., Cary, N.C.

Upchurch, D.R. and J.T. Ritchie. 1983. Root observations using a video recording system in mini-rhizotrons. Agron. J. 75:1009-1015. 